\title{
LETTER
}

\section{Preliminary report on the significance of magmatic enclaves in adakite genesis at Hakusan volcano, central Japan}

\author{
Osamu UJIKE* and Reina MASHIMO** \\ * Graduate School of Science and Engineering, University of Toyama, \\ Gofuku 3190, Toyama 930-8555, Japan \\ ** Department of Earth Sciences, University of Toyama, \\ Gofuku 3190, Toyama 930-8555, Japan
}

\begin{abstract}
Hakusan volcanic rocks younger than the major dormant period $\sim 0.3-0.1$ Ma are adakitic, while those older than the dormant period have geochemical affinities with common island arc andesite, dacite, and rhyolite that are characterized by low $\mathrm{Sr} / \mathrm{Y}$ ratios. The younger lavas, not necessarily adakitic in origin, became adakitic by magmatic mixing with magmatic enclaves (MEs), which are richer in Sr to varying extents and less silicic than the host lavas. We suggest that the younger MEs were derived from adakite magmas that interacted with the upper mantle material during their ascent to the surface. The Sr content in MEs in the older lavas is as low as that in the host lavas. The process of magma generation beneath the Hakusan volcano is likely to have changed between $0.3 \mathrm{Ma}$ and $0.1 \mathrm{Ma}$, from one triggered by the dehydration of the subducted Pacific plate to one caused by the partial melting of the Philippine Sea plate.
\end{abstract}

Keywords: Adakite, Magma, Island arc, Enclaves, Ryohaku Mountains

\section{INTRODUCTION}

The two major processes responsible for generating primary magmas in island arc settings are thought to be (1) partial melting of mantle wedge peridotite metasomatized by the dehydration of the subducted oceanic slab (e.g., Tatsumi and Eggins, 1995), yielding common island arc andesites, dacites, and rhyolites (IAADRs), and (2) partial melting of subducted oceanic crust, yielding adakites (e.g., Defant and Drummond, 1990; Martin et al., 2005). We have found adakitic lavas in addition to lavas having geochemical affinities with common IAADRs from Hakusan, which is the only active volcano in the Ryohaku Mountains, central Japan. In this study, we will outline the geochemical features of adakites and IAADRs in Hakusan volcano; we shall make special reference to magmatic enclaves (MEs hereafter) in lava flows, which provide a clue to the genesis of Hakusan adakitic magmas. Another issue addressed in this study is the plausible change in the subducted oceanic plate, which played a key role in magma genesis over time. This change seems likely because of the presence of two plates subducting in the area-the Philippine Sea (PHS) plate at a shallow lev-

doi:10.2465/jmps.081011

O. Ujike, ujike@sci.u-toyama.ac.jp Corresponding author el and the Pacific (PAC) plate at a deeper level (Fig. 1).

\section{SAMPLES AND ANALYSIS}

Hakusan is a composite volcano comprising the three stratovolcanoes, Kagamuro, Ko-Hakusan, and ShinHakusan, which are arranged in the decreasing order of their ages (Nagaoka et al., 1985). K-Ar age determination results indicate the following: Kagamuro was formed between $0.43 \mathrm{Ma}$ and $0.32 \mathrm{Ma}$, Ko-Hakusan erupted between $0.14 \mathrm{Ma}$ and $0.06 \mathrm{Ma}$, and the active Shin-Hakusan started erupting at $0.03 \mathrm{Ma}$ (Higashino et al., 1984; Sakayori et al., 1999; Kitahara et al., 2000). Lavas of all the three stratovolcanoes are indistinguishable from each other in terms of lithology and petrography. Their phenocrysts (and possibly xenocrysts) always contain plagioclase, orthopyroxene, and amphibole, and sometimes contain olivine, clinopyroxene, biotite, quartz, and opaque minerals. Although not always abundant, round, ellipsoidal, or irregularly shaped MEs are also commonly distributed in the lava flows. The MEs are usually less than 30 $\mathrm{cm}$ in diameter and are porous with vesicles up to 30 vol\% or more. Several plagioclase phenocrysts in the MEs and their host lavas have a dusty zone. The An content outside the zone is higher as compared to that in its 


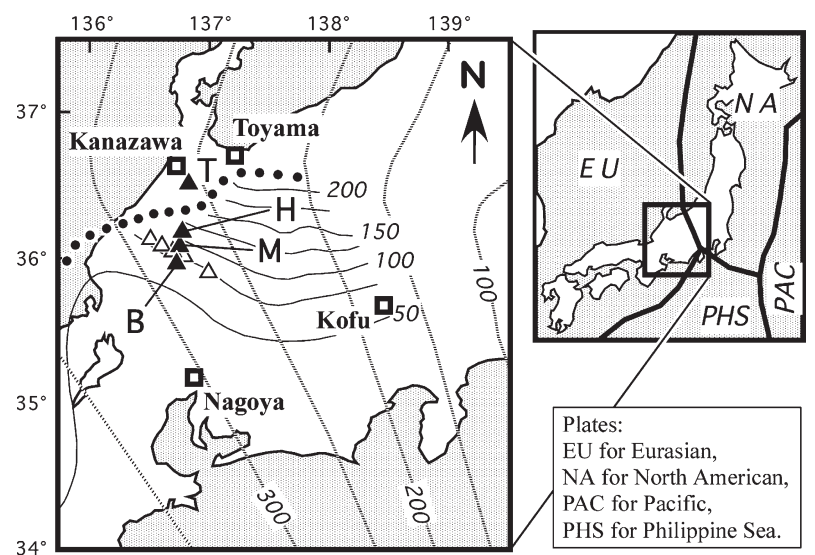

Figure 1. Location of Hakusan volcano. The triangles represent volcanoes (B for Bishamon, $\mathrm{H}$ for Hakusan, $\mathrm{M}$ for RyohakuMaruyama, and T for Tomuro) in the Ryohaku Mountains; solid triangles denote volcanoes younger than $\sim 0.4 \mathrm{Ma}$, while open triangles represent those older than $\sim 0.7 \mathrm{Ma}$ (Tanase et al., 2007). Depth contours of the upper surface of the subducted Pacific plate are shown by thin dotted curves, and those of the subducted Philippine Sea (PHS) plate determined by high-resolution, three-dimensional seismic tomography using arrivaltime data (Nakajima and Hasegawa, 2007) are indicated by solid curves. The dense dotted line between Hakusan and Tomuro volcanoes corresponds to the leading edge of the subducted PHS plate (Nakajima and Hasegawa, 2007).

interior.

Thirty-three rock samples (13 MEs and 20 lava flows) were selected, and their chemical compositions were determined using a Phillips PW2404R X-ray fluo- rescence spectrometer at the Center for Instrumental Analysis, University of Toyama. Glass beads and pressed powders of the samples, together with international geochemical standards as references, were analyzed for major and trace (Rb, Sr, Ba, Y, Zr, Nb, Th, V, and Ni) elements, respectively.

\section{RESULTS}

The MEs are basaltic to andesitic, while the lava flows and essential blocks are andesitic to dacitic in composition (Fig. 2a). All the studied samples are of medium-K type (Le Maitre, 2002) and plot in the calc-alkalic field of Miyashiro (1974) (not shown here). Although the analyses plot almost linearly in some $\mathrm{SiO}_{2}$ variation diagrams (e.g., Fig. 2a), the concentrations of several elements in the samples, especially ME sample, vary considerably for a given $\mathrm{SiO}_{2}$ content (e.g., $\mathrm{Sr}$ and $\mathrm{Zr}$, Figs. 2b and 2c). The ME is generally richer in $\mathrm{Sr}$ than its host lava at Shin-Hakusan and Ko-Hakusan, whereas the ME and its host lava contain similar amounts of $\mathrm{Sr}$ at Kagamuro, as shown by the compositional tie lines in Figure 2b. Rocks from Kagamuro tend to be poor not only in $\mathrm{Na}_{2} \mathrm{O}$ and $\mathrm{K}_{2} \mathrm{O}$ (Nagaoka et al., 1990) but also in Sr. The MEs have a remarkable chemical compositional correlation with their host lavas, as shown in the $\mathrm{Sr}-$ and $\mathrm{Zr}-\mathrm{SiO}_{2}$ variation diagrams; MEs high in $\mathrm{Sr}$ and/or $\mathrm{Zr}$ are present in lavas with high $\mathrm{Sr}$ and/or $\mathrm{Zr}$ content (Figs. $2 \mathrm{~b}$ and $2 \mathrm{c}$ ). It is noted that, among the studied samples, the basaltic enclave is
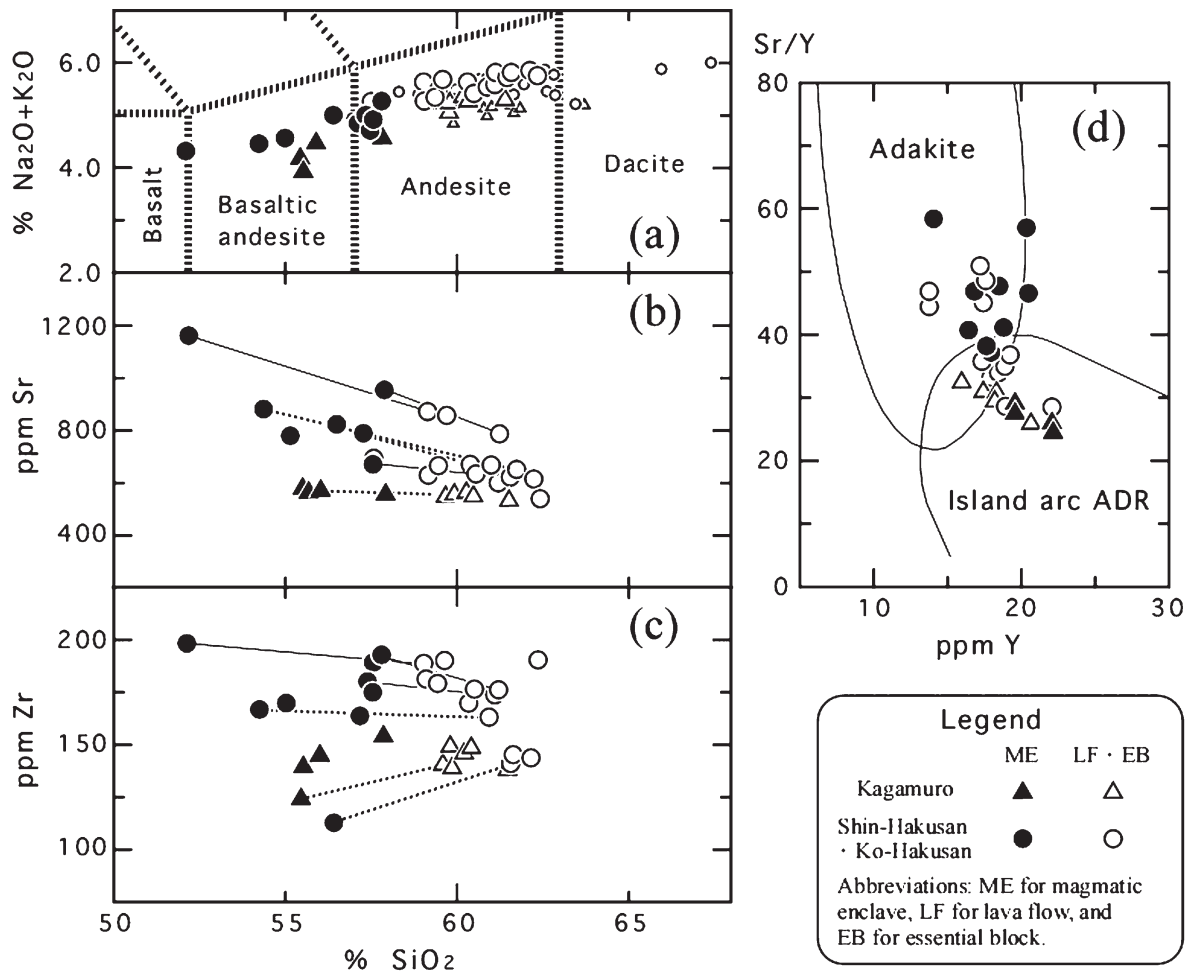

Figure 2. $\left(\mathrm{Na}_{2} \mathrm{O}+\mathrm{K}_{2} \mathrm{O}\right)-\mathrm{SiO}_{2}$ (a), $\mathrm{Sr}-$ $\mathrm{SiO}_{2}$ (b), $\mathrm{Zr}-\mathrm{SiO}_{2}$ (c), and $\mathrm{Sr} / \mathrm{Y}-\mathrm{Y}$ relations between Hakusan volcanic rocks (d). Smaller symbols: data by Nagaoka et al. (1990). Compositional field boundaries in (a) and (d) are from Le Maitre (2002) and Defant et al. (1991), respectively. Representative tie lines between MEs and their host lavas are shown in (b) and (c); data on pairs from Shiramizudaki lava flow (Sakayori et al., 2002) are denoted by solid tie lines. 
the richest in $\mathrm{Zr}$ (Fig. 2c). Figure 2d shows that the samples from Kagamuro are relatively low in $\mathrm{Sr} / \mathrm{Y}$ and plot in the compositional field of common IAADRs; the figure also shows that most samples from Shin-Hakusan and Ko-Hakusan plot in the adakite field.

The basaltic ME from Shin-Hakusan has a composition $\left(51.7 \% \mathrm{SiO}_{2}, 6.5 \% \mathrm{MgO}, 0.6 \% \mathrm{P}_{2} \mathrm{O}_{5}, 1158 \mathrm{ppm} \mathrm{Sr}\right.$, $198 \mathrm{ppm} \mathrm{Zr,} 20 \mathrm{ppm} \mathrm{Y,} 67 \mathrm{ppm} \mathrm{Ni}$, and $57 \mathrm{Sr} / \mathrm{Y}$ ) that lies roughly within the compositional range of low- $\mathrm{SiO}_{2}$ adakites (Martin et al., 2005: $56.3 \pm 3.4 \% \mathrm{SiO}_{2}, 5.2 \pm 1.5 \%$ $\mathrm{MgO}, 0.7 \pm 0.3 \% \mathrm{P}_{2} \mathrm{O}_{5}, 2051 \pm 537$ ppm Sr, $188 \pm 68$ ppm Zr, $13 \pm 3$ ppm Y, $103 \pm 58$ ppm Ni, and $162 \mathrm{Sr} / \mathrm{Y}$ ), even though the ME is lower in $\mathrm{SiO}_{2}, \mathrm{Sr}$, and $\mathrm{Sr} / \mathrm{Y}$ and higher in $\mathrm{Y}$ as compared to the range. On the other hand, even though the analyzed samples are lower in $\mathrm{Sr} / \mathrm{Y}$ and higher in $\mathrm{MgO}$ and $\mathrm{Y}$ as compared to high- $\mathrm{SiO}_{2}$ adakites, the lava samples from Shin-Hakusan and Ko-Hakusan (57.1-62.0\% $\mathrm{SiO}_{2}, 3.0-4.2 \% \mathrm{MgO}, 0.2-0.4 \% \mathrm{P}_{2} \mathrm{O}_{5}, 537-$ 867 ppm Sr, 140-189 ppm Zr, 14-22 ppm Y, 12-40 ppm $\mathrm{Ni}$, and 28-51 Sr/Y) have geochemical affinity with high$\mathrm{SiO}_{2}$ adakites (Martin et al., 2005: $64.8 \pm 2.5 \% \mathrm{SiO}_{2}, 2.2$ $\pm 0.7 \% \mathrm{MgO}, 0.2 \pm 0.2 \% \mathrm{P}_{2} \mathrm{O}_{5}, 565 \pm 150 \mathrm{ppm} \mathrm{Sr}, 108 \pm$ $41 \mathrm{ppm} \mathrm{Zr,} 10 \pm 3 \mathrm{ppm} \mathrm{Y,} 20 \pm 10 \mathrm{ppm} \mathrm{Ni}$, and $56 \mathrm{Sr} / \mathrm{Y})$.

\section{DISCUSSION}

The Shin-Hakusan and Ko-Hakusan lavas probably inherit their adakitic affinity from the ME magmas; the presence of MEs richer in $\mathrm{Sr}$ (and hence, "more adakitic") and the geochemical correlation between MEs and their host lavas (Fig. 2) support this view. The ubiquitous presence of MEs in lava flows indicates the coexistence of two or more magmas before eruption (Bacon, 1986) and suggests that the magmas influenced the chemical composition of each other. Thus, we consider that mafic magmas represented by the MEs must have been responsible for the geochemical affinity of Shin-Hakusan and Ko-Hakusan lavas with adakite.

In variation diagrams, each of the end-member magmas must be positioned on the extensions of compositional tie lines between the MEs and their host lavas before mixing. It is seen in Figure 2 that the compositional tie lines converge to certain areas with around $500 \mathrm{ppm} \mathrm{Sr}$ and $170 \mathrm{ppm} \mathrm{Zr}$ at $70 \% \mathrm{SiO}_{2}$. In other words, even for samples from a single lava (Shiramizudaki flow; Sakayori et al., 2002), the tie lines seem to radiate from the abovementioned areas toward less silicic compositions. Thus, the presumed mafic end-member magmas seem to have differed significantly from each other, with incompatible elemental compositions. On the other hand, the felsic end-member magmas of younger and older rocks could have similar chemical compositions, and they might have been lower crustal partial melts, though there is no evidence to prove this hypothesis.

Since $\mathrm{Zr}$ is one of the incompatible elements in basaltic to andesitic systems, it is unlikely from Figure 2c, where the basaltic ME is observed to be the richest in $\mathrm{Zr}$ among the analyzed samples, that the compositional variations among the ME magmas resulted from crystallization differentiation or the crustal contamination of a single basaltic primary magma. It would be reasonable to consider that the MEs were derived from adakitic magmas that were formed by the partial melting of the subducted oceanic crust (e.g., Defant and Drummond, 1990) and that they reacted with the mantle material to varying extents during their ascent to the surface. The results of melting experiments performed by Rapp et al. (1999) indicate that upon interacting with mantle peridotites, an adakitic melt becomes poorer in $\mathrm{SiO}_{2}$ and richer in several compatible (e.g., $\mathrm{Mg}$ and $\mathrm{Ni}$ ) and incompatible (e.g., $\mathrm{Sr}$ and $\mathrm{Zr}$ ) elements.

The Hakusan volcanic chain is composed of four volcanoes-Tomuro (active at $\sim 0.4 \mathrm{Ma})$, Hakusan $(\sim 0.4-$ $0.0 \mathrm{Ma})$, Ryohaku-Maruyama ( 0.4 Ma), and Bishamon $(\sim 0.3 \mathrm{Ma})$ - in the north-south direction (Fig. 1, age data from Tanase et al., 2007). Among these four volcanoes, Tomuro is the only volcano that did not spew adakitic rocks (Horie and Fujimaki, 1999; Ujike et al., 1999; O. Ujike, unpublished data). It is noted that the distribution of volcanoes that spewed adakitic rocks is restricted to the area where the young PHS plate $(\sim 15 \mathrm{Ma}$ at the Nankai Trough off Shikoku Island; Olafsson, 1993) is subducting (Fig. 1). In addition, all the volcanoes in the Ryohaku Mountains not belonging to the Hakusan volcanic chain are older than $0.7 \mathrm{Ma}$ (Tanase et al., 2007), and, to the authors' knowledge, there has been no evidence confirming the occurrence of adakite in any of them. We propose the following: (1) the dehydration of the subducted PAC plate, which is one of the oldest oceanic plates on earth, triggered the formation of common IAADR-type magmas before the arrival of the subducted PHS plate beneath the Ryohaku Mountains; (2) the leading edge of the subducted PHS plate arrived beneath the southern part of the Hakusan volcanic chain around $0.4 \mathrm{Ma}$ and beneath the Hakusan volcano between 0.3 Ma and 0.1 Ma; and (3) primary adakitic magmas of rather felsic compositions were produced by the melting of the crustal material of the PHS plate. Studies on the temporal relationship between adakitic volcanism and the arrival of the subducted PHS plate beneath central Japan have been made on the basis of magmatisms in the Ryohaku Mountains (Ujike et al., 1999) and in a terrain to the north of the Kofu basin (Shibata et al., 2008; Fig. 1). 


\section{CONCLUDING REMARKS}

In this article, we have suggested that adakitic magmas that erupted from the Hakusan volcano were a mixture of partial melts derived from the oceanic crust of the subducted PHS plate and from the lower crust. Another important suggestion is that the adakitic magmas, represented by the MEs, became less silicic and enriched in incompatible elements through interaction with the upper mantle material. Although these suggestions are among the most plausible explanations for the genesis of adakitic magma, additional data such as those on $\mathrm{Sr}-\mathrm{Nd}-\mathrm{Pb}$ isotope ratios are required to refine it. It is for this reason that we have introduced the term "preliminary report" in the title of this article.

\section{ACKNOWLEDGMENTS}

We thank Drs. Y. Nakamura (Center for Instrumental Analysis) and Y. Ishizaki (Graduate School of Science and Engineering), University of Toyama, for their assistance with the XRF analysis. Comments and encouragement from Dr. T. Shibata and an anonymous reviewer of the journal were helpful in improving the manuscript.

\section{REFERENCES}

Bacon, C.R. (1986) Magmatic inclusions in silicic and intermediate volcanic rocks. Journal of Geophysical Research, 91, 6091-6112.

Defant, M.J. and Drummond, M.S. (1990) Derivation of some modern arc magmas by melting of young subducted lithosphere. Nature, 347, 662-665.

Defant, M.J., Richerson, P.M., De Boer, J.Z., Stewart, R.H., Maury, R.C., Bellon, H., Drummond, M.S., Feigenson, M.D. and Jackson, T.E. (1991) Dacite genesis via both slab melting and differentiation: petrogenesis of La Yeguada Volcanic Complex, Panama. Journal of Petrology, 32, 1101-1142.

Higashino, T., Nagao, K., Itaya, T., Sakata, S. and Yamasaki, M. (1984) K-Ar ages of Quaternary Hakusan and Dainichi-take volcanoes, central Japan. Annual Report of the Hakusan Conservation Center, 10, 23-29 (in Japanese with English abstract).

Kitahara, T., Hori, S., Ogawa, Y., Maekawa, H. and Ishida, K. (2000) Stratigraphy of Shin-Hakusan volcano, central Japan - Examination from result of dating - . Program with Abstracts, 2000 Annual Meeting of The Volcanological Society of Japan, Tokyo, 153 (in Japanese).

Horie, T. and Fujimaki, K. (1999) Petrological characteristics and its spatial variations of volcanic rocks at Hakusan volcanic chain, Ryohaku mountains. Abstracts, 1999 Japan Earth and Planetary Science Joint Meeting, Japan Geoscience Union, Tokyo, Vb-008 (in Japanese with English abstract).

Le Maitre, R.W. (2002) Igneous rocks: a classification and glossary of terms; recommendations of the international union of geological sciences subcommission on the systematics of ig- neous rocks. pp. 236, Cambridge University Press, Cambridge, U.K.

Martin, H., Smithies, R.H., Rapp, R. and Champion, D. (2005) An overview of adakite, tonalite-trondhjemite-granodiorite (TTG), and sanukitoid: relationship and some implications for crustal evolution. Lithos, 79, 1-24.

Miyashiro, A. (1974) Volcanic rock series in island arcs and active continental margins. American Journal of Science, 274, 321355.

Nagaoka, M., Iwata, T., Higashino, T. and Yamasaki, M. (1985) Kagamuro volcano - Forerunner of Hakusan volcano - . Annual Report of the Hakusan Nature Conservation Center, 12, 1-8 (in Japanese with English abstract).

Nagaoka, M., Higashino, T. and Iwata, T. (1990) Bulk rock chemistry of the Hakusan volcano. Annual Report of the Hakusan Nature Conservation Center, 17, 1-11 (in Japanese with English abstract).

Nakajima, J. and Hasegawa, A. (2007) Subduction of the Philippine Sea plate beneath southwest Japan: Slab geometry and its relationship to arc magmatism. Journal of Geophysical Research, 112, B08306, doi:10.1029/2006JB004770.

Olafsson, G. (1993) Calcareous nannofossil biostratigraphy of the Nankai Trough. In Proceedings of the Ocean Drilling Program, scientific results (Hill, I.A., Taira, A., Firth, J.V., Vrolijk, P.J., Winkler, W.R. and Stewart, N.J.. Eds.). College Station, Texas, 131, 3-13.

Rapp, R.P., Shimizu, N., Norman, M.D. and Applegate, G.S. (1999) Reaction between slab-derived melts and peridotite in the mantle wedge: experimental constraints at $3.8 \mathrm{GPa}$. Chemical Geology, 160, 335-356.

Sakayori, A., Higashino, T., Umeda, K., Tanase, A. and Hayashi, S. (1999) K-Ar ages of lavas from Ko-Hakusan volcano, central Japan. Annual Report of the Hakusan Nature Conservation Center, 26, 7-11 (in Japanese with English abstract).

Sakayori, A., Yamada, M., Kobayashi, T. and Kobayashi, K. (2002) Petrological variations of Kengamine and Shiramizudaki lavas, Shin-Hakusan volcano. Bulletin of the Faculty of Education, Natural Science, Kanazawa University. 51, 1-10 (in Japanese).

Shibata, T., Yoshikawa, M. and Koshimizu, S. (2008) Temporal variations of geochemical characteristics of volcanic rocks from north of Kofu Basin, central Japan, and its relationship with the subduction zone structure. MAGMA, 89, 1-16 (in Japanese).

Tanase, A., Oikawa, T., Ninomiya, A., Hayashi, S. and Umeda, K. (2007) Temporal-spatial variations of Plio-Pleistocene volcanic activity in the Ryohaku Mountains, central Japan: evidence from $\mathrm{K}-\mathrm{Ar}$ ages. Bulletin of the Volcanological Society of Japan, 52, 39-61 (in Japanese with English abstract).

Tatsumi, Y. and Eggins, S. (1995) Subduction zone magmatism. pp. 211, Blackwell, Oxford, U.K.

Ujike, O., Tanaka, R. and Watanabe, K. (1999) Petrology of adakitic rocks from Quaternary Bishamon-dake volcano, central Japan. Journal of Mineralogy, Petrology and Economic Geology, 94, 315-328.

\author{
Manuscript received October 11, 2008 \\ Manuscript accepted December 1, 2008 \\ Published online February 9, 2009 \\ Manuscript handled by Jun-Ichi Kimura
}

